\title{
PEMANFAATAN BAWANG PUTIH, KAYU MANIS, CENGKEH, DAN KUNYIT SEBAGAI PAKAN ADITIF MENINGKATKAN PERFORMA BROILER
}

\author{
UTILIZATION OF GARLIC, CINNAMON, CLOVE, AND TURTUMIC AS ADDITIVE \\ FEED TO IMPROVE THE PERFORMANCE OF BROILERS
}

\author{
Dian Lestari $^{1)}$, Woki Bilyaro'), dan Jonathan Anugrah Lase ${ }^{2)}$ \\ ${ }^{1}$ Dosen Program Studi Nutrisi dan Teknologi Pakan Ternak, Fakultas Pertanian dan \\ Peternakan, Universitas Muhammadiyah Kotabumi \\ 2) Balai Pengkajian Teknologi Pertanian (BPTP) Maluku Utara \\ Email : dian.lestari@umko.ac.id
}

\begin{abstract}
Broiler chicken is one of the poultry farm sectors that are much in demand by farmers because of the shorter growth process, but broilers are vulnerable to stress due to extreme climate changes. The purpose of this study was to examine the effectiveness of the use of garlic, cinnamon, clove, and turtumic as feed additives for broilers performance. This study uses a completely randomized design consisting of 5 treatments and 3 replication. The total number of broilers used is 70. Data were processed with analysis of variance (ANOVA) and continued test with Duncan Multiple Range Test (DMRT). The observed variables were feed consumption, final body weight, body weight gain, carcass percentage, and FCR. The results showed that the addition of P0, P1, P2, P3, dan P4 was not-significantly $(P>0,05)$ in increasing the productivity of broiler. However, the use of $1 \%$ cengkeh shows a higher number. The conclusion of this study is the addition of garlic, cinnamon, clove, and turtumic in the feed did not affect the performance of broilers.
\end{abstract}

Keywords: Cinnamon, Clove, Garlic, Performance, Turtumic

\begin{abstract}
Abstrak: Broiler merupakan sektor peternakan unggas yang banyak disukai oleh peternak karena proses pembudidayaan yang lebih singkat, namun broiler rentan terhadap cekaman akibat perubahan cuaca yang ekstrim. Tujuan riset ini adalah untuk menguji efektivitas penggunaan tanaman bawang putih, kayu manis, cengkeh, dan kunyit sebagai pakan aditif untuk meningkatkan perfoma broiler. Riset ini menggunakan desain Rancangan Acak Lengkap yang terdiri atas 5 perlakuan dan 3 ulangan. Total broiler yang digunakan yaitu 70 ekor. Data diolah dengan analysis of variance (ANOVA) dan dilanjutkan dengan uji Duncan Multiple Range Test (DMRT). Peubah yang diamati konsumsi pakan, bobot badan akhir, pertambahan bobot badan, bobot karkas, persentase karkas, dan FCR. Hasil riset membuktikan bahwa penggunaan perlakuan P0, P1, P2, P3, dan P4 belum mampu menjadi alternatif pakan aditif yang meningkatkan performa broiler. Namun penggunaan kayu manis $1 \%$ memperlihatkan angka yang lebih tinggi. Simpulan dari riset ini yaitu
\end{abstract}


penggunaan bawang putih, kayu manis, cengkeh, dan kunyit dalam pakan tidak memberikan pengaruh terhadap performa broiler.

Kata kunci : Bawang Putih, Cengkeh, Kayu Manis, Kunyit, Performa

\section{PENDAHULUAN}

Perkembangan dunia peternakan di Indonesia semakin meningkat dengan pesat. Meningkatnya kebutuhan sumber protein hewani didasari dengan meningkatnya jumlah masyarakat. Protein hewani berupa produksi daging mempunyai prospek yang baik, sehingga ternak yang cukup ideal untuk dikembangkan di Indonesia adalah ternak unggas (Kiramang \& Jufri, 2013). Di Indonesia ternak unggas yang dikembangkan antara lain itik, angsa, entok, ayam buras, dan ayam ras. Peternakan ayam ras pedaging (broiler) merupakan salah satu sektor peternakan unggas yang banyak diminati karena budidaya yang relatif singkat dibandingkan dengan ruminansia. Namun kondisi Indonesia yang memiliki suhu dan kelembaban tinggi sehingga kondisi ini cocok untuk perkembangbiakan mikroorganisme yang dapat mengganggu ketahanan tubuh ternak (Sumarsono, 2008).

Usaha yang dilakukan oleh peternak dalam mengatasi hal tersebut yaitu dengan penggunaan antibiotik sebagai alternatif anti-penyakit pada ternak. Antibiotik dapat mengurangi populasi bakteri di dalam saluran pencernaan sehingga dapat meningkatkan penyerapan zat gizi dari pakan. Namun penggunaan antibiotik yang berlebih dan tidak sesuai dengan dosis dapat menjadi residu yang mengganggu kesehatan manusia. Berdasarkan hasil riset terdahulu, di daerah Jabotabek menunjukkan $85 \%$ dari daging ayam ras pedaging (broiler) dan $37 \%$ hati ayam tercemar oleh residu antibiotik tylosin, penecilyn, oxytetracilyne, dan kanacimyn (Nuningtyas, 2014).

Ayam broiler memiliki kepekaan terhadap suatu substrat dan penyakit sehingga dilakukan pengkajian terkait penggunaan tanaman herbal yang dapat dimanfaatkan sebagai pengganti antibiotik sintetik. Salah satu alternatif yang dapat dilakukan untuk memperbaiki konsumsi, daya cerna, daya tahan tubuh serta mengurangi tingkat stres pada ayam broiler yaitu dengan penggunanan tanaman rempah. Indonesia terkenal sebagai produsen rempah-rempah, tanaman rempah yang potensial sebagai alternatif pengganti antibiotik antara lain kunyit, bawang 
putih, cengkeh, dan kayu manis. Tanaman tersebut telah lama dikenal oleh masyarakat sebagai tumbuhan obat, penyedap makanan, minuman maupun sebagai bahan baku pewangi. Tujuan riset ini adalah untuk menguji efektivitas penggunaan tanaman kunyit, bawang putih, cengkeh, dan kayu manis terhadap perfoma broiler.

\section{METODE}

Metode penelitian menggunakan desain Rancangan Acak Lengkap (RAL) yang terdiri atas 5 perlakuan dan 3 kali ulangan, setiap ulangan terdiri dari 5 ekor. Total broiler yang digunakan yaitu 70 ekor. Pemeliharaan ayam akan dilakukan selama 28 hari dengan menggunakan DOC strain CP
707. Perlakuan yang dilakukan adalah P0 (P0), penggunaan tepung bawang putih (P1), kayu manis (P2), cengkeh (P3), kunyit (P4) dengan level konsentrasi masing-masing sebesar $1 \%$ dari total pakan yang diberikan. Perlakuan mulai diterapkan pada ternak umur 2 minggu. Kandungan nutrisi pakan pada riset ini disajikan pada Tabel 1. Variabel yang diamati pada riset ini adalah konsumsi ransum, bobot badan, pertambahan bobot badan (PBB), konversi pakan, bobot karkas dan persentase bobot karkas. Setelah data diperoleh dan diolah menggunakan software SPSS versi 22. Data yang membuktikan bahwa perbedaan nyata diuji dengan uji Duncan Multiple Range Test.

Tabel 1. Kandungan nutrien pakan dan bahan herbal

\begin{tabular}{lccrrr}
\hline \multirow{2}{*}{ Variabel } & \multicolumn{5}{c}{ Herbal } \\
\cline { 2 - 6 } & $\begin{array}{c}\text { Pakan } \\
\text { Komersil }\end{array}$ & $\begin{array}{c}\text { Bawang } \\
\text { Putih }\end{array}$ & Cengkeh & Kayu manis & Kunyit \\
\hline Air (\%) & 12,03 & 12,19 & 10,62 & 11,22 & 13,10 \\
Abu (\%) & 5,75 & 5,08 & 4,20 & 3,69 & 5,32 \\
Protein (\%) & 19,39 & 17,22 & 18,43 & 10,19 & 6,30 \\
Lemak (\%) & 4,02 & 15,05 & 12,05 & 3,41 & 5,77 \\
Karbohidrat (\%) & - & 11,80 & 10,10 & 2,43 & 13,04 \\
Serat Kasar (\%) & 2,87 & 7,44 & 6,06 & 17,67 & 6,06 \\
\hline
\end{tabular}

*Hasil analisis laboratorium pusat riset sumberdaya hayati dan bioteknologi IPB

\section{HASIL DAN PEMBAHASAN}


Hasil kajian penerapan bawang putih, kayu manis, cengkeh, dan kunyit terhadap performa broiler seperti konsumsi pakan, bobot akhir, PBB disajikan pada Tabel 2, sedangkan FCR, bobot karkas, dan persentase karkas disajikan pada Tabel 3.

Tabel 2. Konsumsi Pakan, Bobot Akhir, dan PBB selama 28 hari

\begin{tabular}{lrrr}
\hline Perlakuan & \multicolumn{3}{c}{ Variabel } \\
\cline { 2 - 4 } & Konsumsi pakan & Bobot akhir & PPB \\
& -------------- (g/ekor)----------- \\
\hline P0 & $2.537,99 \pm 0,06$ & $1.424,86 \pm 0,13$ & $1.382,26 \pm 0,06$ \\
P1 & $2.586,96 \pm 0,03$ & $1.438,77 \pm 0.08$ & $1.395,87 \pm 0,02$ \\
P2 & $2.609,01 \pm 0,01$ & $1.498,57 \pm 0,01$ & $1.457,14 \pm 0,04$ \\
P3 & $2.499,87 \pm 0,01$ & $1.399,31 \pm 0.20$ & $1.358,21 \pm 0.04$ \\
P4 & $2.550,69 \pm 0,05$ & $1.320,88 \pm 0,01$ & $1.378,68 \pm 0,01$ \\
\hline Rataan & $2.556,92 \pm 0,08$ & $1.416,52 \pm 0,02$ & $1.394,44 \pm 0,05$
\end{tabular}

Keterangan : Kontrol $=\mathrm{P} 0 ; \mathrm{P} 1=$ Bawang putih $1 \% ; \mathrm{P} 2=$ Kayu manis $1 \% ; \mathrm{P} 3=$ cengkeh $1 \% ; \mathrm{P} 4=$ Kunyit $1 \%$

\section{a. Pengaruh Perlakuan terhadap Konsumsi Pakan pada Broiler}

Berdasarkan hasil analisis konsumsi pakan, penerapan aditif ini (bawang putih, kayu manis, cengkeh dan kunyit) tidak berbeda nyata dengan kontrol $(\mathrm{P}>0,05)$. Hal ini menunjukkan perlakuan yang diberikan tidak mempengaruhi jumlah konsumsi pakan dan palatabilitas pada ayam broiler. Hasil riset ini sejalan dengan Barreto dkk. (2008) penggunaan ekstrak kayu manis (1000 ppm) dalam ransum broiler tidak menunjukkan pengaruh yang nyata terhadap konsumsi pakan.
Namun total konsumsi pakan riset ini lebih tinggi dibandingkan dengan standar konsumsi pakan seekor broiler. Konsumsi pakan pada riset ini rata-rata 639,23 g/ekor/minggu, sedangkan menurut Rasyaf (2003) rata-rata konsumsi pakan broiler adalah 456,67 g/ekor/minggu.

Total konsumsi pakan selama riset tertinggi pada perlakuan P2. Kondisi ini diduga karena kayu manis mengandung eu-genol dan atsiri-oil yang dikenal efektif sebagai anti-mikroba dan jamur, sehingga mampu menghambat pertumbuhan bakteri jahat dalam saluran pencernaan. Variabel tersebut 
diduga membantu saluran pencernaan sehingga dapat mempertahankan jumlah pakan yang dapat dikonsumsi. Pada perlakuan P3 menunjukkan data konsumsi terendah. Penurunan konsumsi pakan diduga karena aroma dan rasa pedas yang ditimbulkan oleh cengkeh sehingga kurang disukai oleh broiler. Hasil ini didukung oleh Herlina dkk. (2015), penerimaan pakan oleh unggas dipengaruhi oleh rasa, testur, dan bau. Unggas memiliki sistem perasa berupa gustative of taste buds pada lidahnya sehingga dapat mengenali cita rasa makanannya, tetapi indera penciuman pada ayam (olfactory system) kurang berkembang.

Berdasarkan oleh itu, maka dilakukan pengukuran pada nilai FCR, bobot dan persentase karkas yang disajikan pada tabel berikut :

Tabel 3. FCR, Bobot Karkas, dan Persentase Karkas selama 28 hari

\begin{tabular}{lccc}
\hline Perlakuan & FCR & $\begin{array}{c}\text { Variabel } \\
\text { Bobot karkas } \\
\text { (g/ekor) }\end{array}$ & Persentase karkas $(\%)$ \\
\cline { 2 - 4 } & $1,78 \pm 0,01$ & $1.001,71 \pm 0,03$ & $70,30 \pm 0,05$ \\
P0 & $1,80 \pm 0,00$ & $1.012,04 \pm 0,01$ & $70,34 \pm 0,05$ \\
P2 & $1,74 \pm 0,01$ & $1.056,89 \pm 0,01$ & $70,53 \pm 0,03$ \\
P3 & $1,79 \pm 0.01$ & $980,81 \pm 0,05$ & $70,09 \pm 0,02$ \\
P4 & $1,93 \pm 0,00$ & $998,90 \pm 0,02$ & $70,30 \pm 0,02$ \\
\hline Rataan & $1,81 \pm 0,06$ & $1.010,07 \pm 0,00$ & $70,31 \pm 0,02$ \\
\hline Keterangan $:$ & P0 & P &
\end{tabular}

Keterangan : Kontrol $=\mathrm{P} 0 ; \mathrm{P} 1=$ Bawang puth $1 \% ; \mathrm{P} 2=$ Kayu manis $1 \% ; \mathrm{P} 3=$ cengkeh $1 \% ; \mathrm{P} 4=$ Kunyit $1 \%$

\section{b. Pengaruh Perlakuan Terhadap FCR}

FCR dapat menjadi acuan untuk mengetahui kemampuan ternak dalam mengubah pakan menjadi daging dengan satuan waktu tertentu. Semakin tinggi FCR maka PBB semakin rendah dan konsumsi pakan yang tinggi. Peningkatan angka FCR menandakan bahwa ayam kurang efisien dalam memanfaatkan pakan untuk pertumbuhan. Hasil analisis statistik membuktikan bahwa perlakuan yang diberikan non-signifikan $(\mathrm{P}>0,05)$ dengan P0. Berdasarkan Amrullah 
(2003), nilai FCR pada riset ini masih berada pada kisaran yang baik yakni antara 1,75-2,00. Berdasarkan angka, rataan nilai FCR pada riset yakni 1,81 \pm 0,06. Nilai ini menunjukkan bahwa dalam menghasilkan $1 \mathrm{~kg}$ bobot badan broiler membutuhkan $1,81 \mathrm{~kg}$ pakan. Pada proses pemeliharaan broiler, nilai FCR sangat berkaitan dengan nilai ekonomi dan jumlah pakan. Semakin tinggi nilai FCR maka jumlah pakan yang dikonsumsi semakin tinggi sehingga mengurangi keuntungan yang diperoleh peternak.

\section{c. Produktivitas Ayam Broiler yang diberi Perlakuan}

Hasil analisis statistik menunjukkan bahwa pemberian bawang putih, kayu manis, cengkeh dan kunyit non-signifikan $(\mathrm{P}>0,05)$ terhadap bobot badan dan PBB. Bobot badan akhir dapat tercapai sesuai target yang diharapkan jika kualitas pakan, manajemen pemeliharaan, dan kondisi ternak sehat. Pada riset ini rataan bobot badan akhir broiler yakni 1.416,52 g/ekor. Hasil riset ini sejalan dengan standar PT Charoen Pokphand. Menurut PT. Charoen Pokphand (2006), standar bobot badan broiler umur 4 minggu yaitu 1.467 g/ekor. Rataan bobot badan broiler pada riset ini memenuhi standar karena nutrisi dan suhu kandang optimum sehingga pemanfaatan pakan menjadi daging lebih optimal. Berdasarkan angka, perlakuan P2 menampilkan bobot badan akhir lebih tinggi dibandingkan dengan P0. Kondisi ini sejalan dengan Ebrahimi (2013) yang menyatakan bahwa penggunaan tepung kayu manis dapat membantu kinerja pencernaan, menurunkan kontaminasi E. Coli, dan mengoptimalkan bobot badan broiler. Pada kisaran angka, perlakuan P3 memiliki bobot badan dan PBB lebih rendah dibandingkan dengan P0. Kondisi ini diduga karena penggunaan tepung cengkeh sebanyak $1 \%$ memberi rasa pedas sehingga konsumsi pakan lebih rendah dan produktivitas terhadap produksi daging kurang optimal. Kondisi ini membuktikan bahwa adanya korelasi antara konsumsi pakan dan pertumbuhan pertambahan bobot badan.

Berdasarkan Tabel 2. Perlakuan P4 dan P1 juga belum mampu meningkatkan bobot badan dan PBB pada broiler. Hasil ini berbeda dengan riset Nuningtyas (2014) yang membuktikan bahwa penggunaan $0,08 \%$ bawang putih dapat meningkatkan PBB. Perbedaan ini diduga karena perbedaan dosis yang lebih tinggi mengakibatkan terjadi kelebihan protein dan kurang efisien 
untuk meningkatkan PBB. Pada P4 membuktikan bahwa rataan yang tidak berbeda dengan P0. Kondisi ini diduga penggunaan kunyit sebanyak $1 \%$ tidak mengubah rasa pada pakan sehingga konsumsi pakan tidak berbeda dengan $\mathrm{P} 0$.

Bobot karkas dan persentase karkas selama riset masih nonsignifikan dengan kontrol $(\mathrm{P}>0,05)$. Namun berdasarkan angka, P2 memiliki bobot dan persentase karkas yang lebih tinggi dibandingkan dengan P0. Hasil ini berbanding lurus dengan data jumlah konsumsi pakan dan PBB yang juga lebih tinggi sehingga FCR terhadap bobot karkas lebih efisien. Kondisi ini membuktikan bahwa proporsi karkas yang dihasilkan akan sejalan dengan bobot potong, yaitu semakin tinggi bobot potong maka bobot karkas yang dihasilkan juga semakin tinggi (Lestari dkk., 2017). Rataan bobot dan persentase karkas yang tidak berbeda membuktikan bahwa bobot potong sangat menentukan bobot karkas dan persentase karkas. Variabel-variabel yang diduga dapat mempengaruhi bobot karkas dan persentase karkas antara lain jenis kelamin, umur potong, kesehatan, nutrisi pakan, durasi pemuasaan, dan bobot akhir atau bobot potong.

\section{PENUTUP}

\section{a. Simpulan}

Penggunaan perlakuan P0, P1, P2, P3, dan P4 belum mampu menjadi alternatif pakan aditif yang meningkatkan performa broiler.

\section{b. Saran}

Sebaiknya perlu dilakukan kajian lebih lanjut terhadap zat fitokimia tanaman herbal.

\section{DAFTAR PUSTAKA}

Amrullah, I. K. (2003). Nutrisi Ayam Broiler. Ed.1. Bogor : Lembaga Satu Gunung Budi.

Barreto, M. S. R., Menten, J. F. M., Racanicci, A. M. C., Pereira, P. W. Z., \& Rizzo, P. V. (2008). "Plant Extracts Used As Growth Promoters In Broilers". J. Poult Sci. Vol. 10 (2) : 109--115.

Ebrahimi M, Hoseini A, Palizdar MH, Mohamadian-Tabrizi HR, \& Porelmi MR. (2013). "Effect of Cinnamon, Red Pepper, Ginger and Cumin on Broiler's Performance". Anim Vet Sci. Vol. $3(5): 131--135$.

Herlina, B., Novita, R., \& Karyono, T. (2015). "Pengaruh Jenis dan 


$\begin{array}{ll}\begin{array}{l}\text { Waktu Pemberian } \quad \begin{array}{r}\text { Ransum } \\ \text { Performans }\end{array} \\ \text { terhadap }\end{array} & \begin{array}{l}\text { Sembung (Blumea Balsamifera) } \\ \text { dalam Ransum terhadap Performa }\end{array} \\ \text { Pertumbuhan dan Produksi Ayam } & \text { Ayam Broiler. Skripsi. Bogor: } \\ \text { Broiler". J. Sain Peternakan } & \text { Institut Pertanian Bogor. }\end{array}$

Indonesia. Vol. 10 (2) : 107-113.

Kiramang, K., \& Jufri, M. (2013).

"Pengaruh Pemberian Serbuk

cinnamon (Syzygium

Aromaticum) pada Ransum terhadap Performan Broiler". J. Teknosains. Vol. 7 (2) : 219--230.

Lestari, D., Rukmiasih, Suryati, T., \& Hardjosworo, P. S. (2017). "Performa Itik Lokal (Anas platyrhynchos Javanica) yang diberi TepungDaun Beluntas atau Kenikir sebagai Sumber Pakan Aditif'. JIPTHP. Vol. 5 (1) : 34-40.

Nuningtyas, Y. F. (2014). "Pengaruh Penambahan Tepung Garlic (Allium Sativum) sebagai Aditif terhadap Penampilan Produksi Ayam Pedaging". J. Ternak Tropika. Vol. 15 (1) : 21--30.

PT. Charoen Pokphand Jaya Farm Indonesia. (2006). Manual Manajemen Layer dan Broiler. CP 707. Lampung : PT. Charoen Pokphand Jaya Farm Indonesia.. Rasyaf, M. (2003). Beternak Ayam Petelur. Yogyakarta: Kanisius. Sumarsono, H. O. P. (2008). Pengaruh Penggunaan Tepung Daun 